\title{
Article
}

\section{A study on adulteration in cereals and bakery products from Poland including a review of definitions}

Kowalska, Aleksandra, Soon, Jan Mei and Manning, Louise

Available at http://clok.uclan.ac.uk/22726/

Kowalska, Aleksandra, Soon, Jan Mei ORCID: 0000-0003-0488-1434 and Manning, Louise (2018) A study on adulteration in cereals and bakery products from Poland including a review of definitions. Food Control . ISSN 0956-7135

It is advisable to refer to the publisher's version if you intend to cite from the work. http://dx.doi.org/10.1016/j.foodcont.2018.05.007

For more information about UCLan's research in this area go to http://www.uclan.ac.uk/researchgroups/ and search for < name of research Group>.

For information about Research generally at UCLan please go to http://www.uclan.ac.uk/research/

All outputs in CLoK are protected by Intellectual Property Rights law, including Copyright law. Copyright, IPR and Moral Rights for the works on this site are retained by the individual authors and/or other copyright owners. Terms and conditions for use of this material are defined in the policies page.

\section{CLoK}

Central Lancashire online Knowledge www.clok.uclan.ac.uk

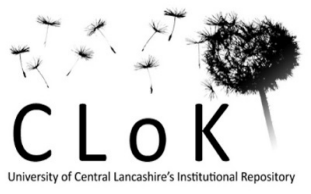




\section{Accepted Manuscript}

A study on adulteration in cereals and bakery products from Poland including a review of definitions

Aleksandra Kowalska, Jan Mei Soon, Louise Manning

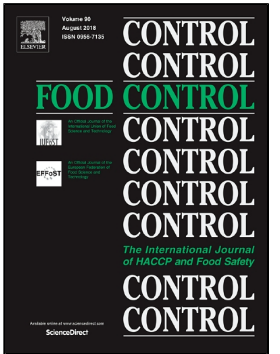

PII:

S0956-7135(18)30232-9

DOI:

10.1016/j.foodcont.2018.05.007

Reference:

JFCO 6131

To appear in:

Food Control

Received Date:

16 March 2018

Revised Date:

03 May 2018

Accepted Date:

05 May 2018

Please cite this article as: Aleksandra Kowalska, Jan Mei Soon, Louise Manning, A study on adulteration in cereals and bakery products from Poland including a review of definitions, Food Control (2018), doi: 10.1016/j.foodcont.2018.05.007

This is a PDF file of an unedited manuscript that has been accepted for publication. As a service to our customers we are providing this early version of the manuscript. The manuscript will undergo copyediting, typesetting, and review of the resulting proof before it is published in its final form. Please note that during the production process errors may be discovered which could affect the content, and all legal disclaimers that apply to the journal pertain. 
A study on adulteration in cereals and bakery products from Poland including a review

of definitions

Authors

\section{ALEKSANDRA KOWALSKA ${ }^{1}$, JAN MEI SOON $^{2}$ AND LOUISE MANNING $^{3}$}

${ }^{1}$ Department of Quality and Knowledge Management, Faculty of Economics, Maria CurieSkłodowska University, Lublin, Poland aleksandra.kowalska@umcs.lublin.pl

${ }^{2}$ International Institute of Nutritional Sciences and Applied Food Safety Studies, School of Sport and Wellbeing, University of Central Lancashire, Preston PR1 2HE UK jsoon@uclan.ac.uk

${ }^{3}$ Department of Food Science and Food Supply Chain Management, Harper Adams University, Newport, Shropshire, UK TF10 8NB 1manning@harper-adams.ac.uk

Corresponding author email address: aleksandra.kowalska@umcs.lublin.pl

\section{Abstract}

The aim of the study was to critique the food adulteration trends associated with cereals and bakery products from Poland. The methodological approach was to firstly review existing literature to define and outline the challenge of food adulteration and the degree of harmonisation, or not, of definitions, and then to analyse local and European data on the prevalence of food adulteration and mislabelling in the cereals and bakery sector more generally, and specifically in Poland. Analysis of general RASFF notifications of cereal and bakery products linked to Poland $(n=177)$ revealed that most non-compliances were due to mycotoxins, undeclared allergens and undeclared genetically modified materials. Key notable trends included an increase in incorrect allergen labelling with only two incidents directly associated with adulteration firstly with melamine and also suspicion of deliberate contamination of milk powder with rodenticide. Data from IJHARS share similar trends where most reported irregularities associated with cereal and bakery products were related to mislabelling. The definition of adulterated foodstuffs in Poland concentrates on mislabelling particularly regarding product composition rather than being differentiated by the motivation 
of the perpetrator. This is not in step with other definitions where intent is seen an inherent aspect of a determination of an instance of food fraud or adulteration. This work demonstrates that even in harmonized regulatory areas such as the EU there are local definitions of adulteration that due to the lack of consistency could influence collective approaches to determining the extent of or addressing the problem of mislabelling, misrepresentation and misbranding as a form of adulteration.

\section{Highlights}

- Most commonly reported adulterated cereal and bakery products in Poland were bread and pasta.

- Most cases of food adulteration were related to mislabelling

- More research needed to contextualise drivers for mislabelled and misrepresented products.

Key words: adulteration, mislabelling, motivation, misbranded, bread, misrepresented

\section{Abbreviations non-standard}

None

\section{Funding}

This research did not receive any specific grant from funding agencies in the public, commercial or not for profit sectors 
49

\section{Introduction}

Following the 2013 horsemeat scandal, there has been resurgence in public and business interest in food fraud. Indeed, assuring food authenticity and mitigating adulteration have been major drivers for establishing food regulations worldwide (Kölbener, Bieri \& St-Gallen, 2016). Food fraud is defined by the United Kingdom (UK) Food Standards Agency (FSA) as: "deliberately placing food on the market, for financial gain, with the intention of deceiving the consumer" (Elliott Review, 2014), although food safety concerns exist (Moore, Spink, \& Lipp, 2012). Food fraud includes the subcategory of economically motivated adulteration (EMA) i.e. deception for economic gain using food products, ingredients and packaging including activities such as substitution especially with substandard or inferior products, unapproved additions or enhancements, misbranding or misrepresentation, tampering, counterfeiting, using stolen goods and others (Spink \& Moyer, 2011; GFSI, 2014; Manning \& Soon, 2014; BRC, 2015; Manning, 2016).

However, there is a lack of harmonisation of definitions and uses of the term "adulteration". The previous definition refers to EMA, but food adulteration can be simply be when a product contains an element or ingredient which is fraudulent (Spink \& Moyer, 2011) or else adulteration can be described as the actions that are taken to add or adjust a food item or composite food product by the use of extraneous, substandard, or inferior ingredients (Manning \& Soon, 2014). Bansal, Singh, Mangal, et al. (2017) in their work on the problems with adulterated food products in India state that "food adulteration can be defined as lowering the quality of food by intentional or unintentional substitution of food with some inferior foreign particle or by removal of some value added food substitute from main food item". This latter definition contests that both intentional and unintentional actions which can affect quality, and safety may be classed as adulteration. This demonstrates an inconsistency in the way terms 
are derived and used when considering food adulteration.

The challenge of food adulteration is complex with multiple factors of influence including market competition, supply chain pressure and power dynamics, resource scarcity, inadequate governance, lack of sanctions and low probability of discovery, rapid development of systems, logistics and technology, data swamping and opacity (Charlebois, Schwab, Henn, \& Huck, 2016; Manning, Smith \& Soon, 2016; Marvin et al., 2016). Food adulteration has been associated with high value food such as olive oil (Garrido-Delgado, Munoz-Perez \& Arce, 2018), honey (Amiry, Esmaiili \& Alizadeh, 2017) and herbs and spices (Silvis, van Ruth, van der Fels-Klerx \& Luning, 2017; Galvin-King, Haughey \& Elliott, 2017). Although luxury items are perceived to be more likely to be targeted by fraudsters, generally they are not eaten in the same quantity as cereal-derived products. Indeed, the very first piece of public health legislation passed in the UK was the 1757 "Act for the due making of Bread; and to regulate the Price and Assize thereof; and to punish Persons who shall adulterate Meal, Flour, or Bread." (Scally, 2013 , p. 346). Thus, it can be argued that there is potentially a greater risk of cumulative financial and personal harm from adulterated foods that are eaten and purchased more often and in larger amounts. This forms the research rationale for why cereal-derived products are the focus of this research.

\section{Methodology and research rationale}

Cereal grains such as wheat and derived flour are major ingredients for the most important staple foods in the EU such as breads, pasta, cakes, and biscuits (Murniece \& Straumite, 2014; Cozzolino, 2016; Geng, Harnly, \& Chen, 2016). Poland is one of the major cereal producers in the EU and in 2015 exported more than $20 \%$ of the total cereal produced (CSO, 2016a) highlighting the risk to illicit activity associated with Polish cereals and bakery products and the impact within Poland and also for other countries. Appropriate prevention 
measures can only be implemented if the nature and type of illicit activity is understood (Tähkäpää, Maijala, Korkeala, \& Nevas, 2015). Thus, this research aims to determine and analyse the extent of reported food adulteration cases in cereals and baked goods in Poland in order to identify potential trends and frame the development of future empirical research in this area.

Food adulteration cases were analysed at two reporting and control system levels (EU and national levels in Poland) and iterative analysis identified potential patterns of incidence. The EU Rapid Alert System for Food and Feed (RASFF) database was searched using the product category 'cereals and bakery products' and hazard category 'adulteration/fraud', 'labelling absent/incomplete/incorrect', and 'composition'. A further search in RASFF using 'Poland' under the country origin was also conducted. Similarly, we retrieved and analysed all 'Adulterated agri-food items' notified in the Agricultural Food and Quality Inspection (IJHARS) site from 2010 - 2017. A previous study by Kowalczyk (2015) used IJHARS food inspection data to assess the main areas of food fraud, but was not specific to cereals and bakery products, thus making the research described herein of interest. We have structured the paper as follows: Section 1 is an introduction and a brief overview of food adulteration terminology; and Section 2 provides the underlying rationale and the methodology employed. Section 3 synthesizes existing literature and considers secondary data to review cereal production and manufacture of cereal based and bakery products in Poland and the resultant value to the Polish economy. Section 4 provides a brief review of the local (IJHARS) and international (RASFF) databases and reviews the data derived in this research. In Section 5 results are presented and discussed. Section 6 concludes the paper and seeks to identify potential trends and frame the development of future empirical research.

\section{Background to the Polish cereal sector}

\subsection{Agricultural cereal production in Poland and associated exports}



an established place in food culture in Northern and Eastern Europe (Pohjanheimo, Paasovaara, Luomala \& Sandell, 2010; Murniece \& Straumite, 2014). In 2015, Poland exported 21.8\% of its total cereal production, which accounted for $2.7 \%$ of Polish GDP. The main export product was wheat and spelt with key export markets being Germany, Egypt, Saudi Arabia, Algeria, and Morocco. The value of Polish cereal products exports (bread, pastry, cakes, biscuits, wafers etc.) accounted for $99.8 \%$ of the total value of cereal exports in 2015 (CSO, 2016a). Poland is the third largest cereal producer in the EU-28 after France and Germany. Analysing the structure of utilised agricultural area (UAA) identifies the dominant role of cereals in national production (Czyżewski \& Staniszewski, 2016) with Denmark (55\%), Poland (52\%) and a significantly lower share in Germany (39\%) and France (35\%) producing the majority of cereal in EU. Common organisation of the cereals market was initiated in the late $60 \mathrm{~s}$ of the $20^{\text {th }}$ century and EU Member States benefited from intervention buying, storage and sale of cereals through the evolution of the Common Agricultural Policy (CAP). In 2015, the quantities of rye and meslin produced in Poland account for $28.5 \%$ of the total EU production of those cereals (Europa, nd). The combined volume of cereal production places Poland second among other EU Member States in terms of output. Moreover, Poland is the largest oats producer contributing $16 \%$ of 2015 EU production. In Poland, oats are used in industrial processing e.g. for energy purposes (Kawka \& Achremowicz, 2014; Głowacka, Zych \& Żołnierczuk, 2016), and are a valuable source of nutrients and multiple bioactive compounds, being used widely in gluten-free products (Pinto-Sánchez et al.; 2017). More recently, spelt is of particular interest in Poland with organic farmers, because of its high nutrient content, lower habitat requirements and impact (Knapowski et al., 2017) and cost-effectiveness of production (Kowalska, 2010).

\subsection{The influence of socio-economic changes in Poland on consumption and supply chain structure}


149

150

151

152

153

154

155

156

157

158

159

160

161

162

163

164

165

166

167

168

169

170

171

172

173

The socio-economic transformation of Poland has contributed to qualitative and quantitative changes in the national food consumption. National data from 2003-2015 suggests Poles are eating less, but better food (the caloric content is reducing, while the nutritional value of the average portion size is increasing) and more expensively while eating more frequently outside the home (Świetlik, 2017). Despite consumption systematically decreasing across all socioeconomic groups of the Polish population (Stanisławska \& Kurzawa, 2016), bakery and cereal products still hold a key position, as average monthly per capita consumption in Polish households is only second to the consumption of vegetables, including potatoes (CSO, 2016b). Moreover, on the basis of Polish history, culture and prevalent religion, bread is culturally respected within the diet but despite this, bread is one of the most often wasted food in Polish households (Śmiechowska \& Chrzanowska, 2015; Kowalska, 2017).

In 2015, there were 154 Polish pasta production plants (CSO, 2016c). Consolidation of the pasta and noodles market has occurred, but national demand is still showing an upward volume trend. Whilst being a leading producer of bread and cereals compared with other EU countries, on the supply side, there were 8543 bakeries and confectioneries in Poland in 2015 (CSO, 2016c). Mostly small local enterprises they hold a relatively weak business position in the context of global supply chains being at a competitive disadvantage with both large-format stores and material suppliers, and as a result the number of small bakeries is continuously decreasing. However, these businesses often have good reputation in the communities in which they operate. Such a difficult commercial situation is not unique in the Polish food industry. Therefore, a law on prevention of unfair use of contract advantage in marketing of agricultural and food products was adopted in 2016 (The Act on the Prevention... 2016). Consideration of these small bakeries shows worse financial performance, but at the same time a higher social and environmental performance when compared with global businesses. 
Although adoption was a legal requirement, two years after the accession of Poland to the EU, the level of hazard analysis critical control point (HACCP) system implementation in bakeries, confectionaries and cereal-miller production plants was relatively low being $10-40 \%$ of those businesses legally required to implement HACCP (Kowalska, 2010). Generally, small and medium enterprises in Poland had economic difficulties when implementing HACCP (Trafiałek \& Kołożyn-Krajewska, 2011). However, by 2015, about $80 \%$ of bakeries, confectionaries and cereal-miller production plants were compliant (CSO, 2016c). National data from 2005-2015 demonstrates the sanitary state of these establishments (disqualified samples as a percentage of samples tested), suggesting that sanitary and food hygiene conditions have also improved (CSO 2016c).

The strategic national aim is to build competitive advantage for Polish cereals and bakery on the global market, thus demonstrating consistent, excellent food safety standards, product integrity and authenticity and engendering supply chain and consumer trust underpin this ambition. Effective Polish legislation regarding the issue of food adulteration and also the Polish food control institutions' activities in this area will significantly contribute to ensuring legal compliance. Protecting consumer health and life is a major concern addressed by both EU food law and Member State food control activities as well as mitigating fraudulent, deceptive and other misleading practices that could harm the economic interests of consumers, national GDP and the wider food industry. These are now explored.

\section{Databases analysed and derived data}

\subsection{Agricultural and Food Quality Inspection (IJHARS), Poland}

Article 9.1(b) of Regulation EU 2017/625 on official controls and other official activities performed to ensure the application of food and feed law .... of $15^{\text {th }}$ March 2017 states that: Competent authorities shall perform official controls on all operators regularly, on a risk basis and with appropriate frequency, taking account of: .. any information indicating the 
199 likelihood that consumers might be misled, in particular as to the nature, identity, properties,

200

201 composition, quantity, durability, country of origin or place of provenance, method of manufacture or production of food. Two Polish laws aim to protect the consumer in the food chain:

1. The Act on the Safety of Food and Nutrition (2006) which lays down rules and procedures in order to ensure food and nutrition safety regarding any health implications for consumers, and

2. The Act on Commercial Quality of Agricultural and Food Products (2000) which regulates quality issues and their economic implications for consumers (u.j.h.).

The definitions of fraudulent foodstuffs introduced by the two aforementioned Acts concentrates on mislabelling, mostly regarding product composition. Under Article 3 of the Polish Act on Safety of Food and Nutrition, adulterated foodstuff is determined in these regulations as a foodstuff whose composition or other properties were changed without informing the consumer about it, or a foodstuff changed in order to conceal its intrinsic composition or other properties, and affecting the safety of the foodstuff. Under Article 3 of u.j.h., adulterated agricultural and food product is defined as a product whose composition does not comply with the provisions of regulations regarding commercial quality of individual foodstuffs, or a product changed (including mislabelling) in order to conceal its intrinsic composition or other properties, as long as the mentioned non-compliances or changes significantly violate consumer interests. Herein the term adulterated focuses on the inherent, intrinsic state of the food rather than the motivation of the perpetrator, which differs from the definitions outlined in the introduction. This lack of harmonisation is a very important point because in Poland, the business operator that produces or places adulterated food on the market, carries administrative, criminal and/or civil liability for the action (The Act on Commercial 
Quality... 2000; The Act on the Safety of Food... 2006), irrespective of there being an intent to mislead.

The Agricultural and Food Quality Inspection (IJHARS) in Poland takes both control and preventive actions for issues that could affect consumers' safety and food authenticity along the whole food supply chain, excluding retail trade (in the hands of Trade Inspection, IH). The provincial inspector of IJHARS is entitled to issue administrative decisions concerning: a) prohibiting the marketing of adulterated product, reprocessing or discarding adulterated product, etc., (Article 29 paragraph 1 u.j.h).; and b) imposing a financial penalty on the operator that places adulterated food on the market (Article 40a u.j.h.). Both IJHARS and IH conduct border inspections of exported/imported agri-food products. The IJHARS publishes administrative decisions associated with food adulteration on-line including: number and date of the decision regarding detected food adulteration, legal basis of the decision, the name of a particular product concerned, the number of production batch and the date of production, batch volume, confirmed irregularities, and the name of an entity that places the food on the market. The public is not informed about the details of actions undertaken in relation to food adulteration detection. Further, the information (intelligence) and its source are not generally known.

\subsection{Rapid Alert System for Food and Feed (RASFF)}

The EU RASFF database is a centralised platform developed to ensure the safety of food and animal feed in the EU. Members, including the EC, EU members, European Food Safety Authority (EFSA), European Free Trade Association [EFTA] Surveillance Authority, (i.e. Iceland, Liechtenstein and Norway) and Switzerland, are obliged to notify and to exchange information on food safety issues and measures (RASFF, 2017). The RASFF database provides members with a tool for exchanging information about measures taken in response to serious risks detected in relation to food and feed both internally within the country and at border 
inspection points (Tähkäpää et al., 2015). An alert is the highest level of notification to inform member countries that the food, feed or food contact material present a serious risk on the market and rapid action is or might be required (RASFF, 2017). The six food fraud categories in the EU RASFF database are: improper, fraudulent, missing or absent health certificate; illegal or unauthorised import, trade or transit; adulteration, fraud or tampering; improper, expired, fraudulent or missing common entry document (CED), import declaration, or analytical report; expiration date; and mislabelling (Bouzembrak \& Marvin, 2015). Within the hazard category 'labelling absent/incomplete or incorrect' categories include: insufficient labelling such as absence of allergen declaration, incorrect labelling e.g. incorrect or absent declaration of gluten free status. The RASFF (2017) composition category includes categories such as unauthorised presence of colours or other materials, or excess content of vitamins, metals (such as aluminium).

Multiple studies have analysed RASFF data for incident frequency and trends (Kleter, Prandini, Filippi, \& Marvin, 2009; Tähkäpää et al., 2015; Bouzembrak \& Marvin, 2015; Marvin et al., 2016; Djekic, Jankovic \& Rajkovic, 2017). Analysis of RASFF data has focused on microbiological and chemical hazards rather than physical hazards and of the foreign body notifications analysed in their study for Eastern Europe $(n=411), 93 \%$ were attributed to pest contamination (Djekic et al,. 2017). This work classified Eastern Europe as Bulgaria, Czech Republic, Hungary, Poland, Romania and Slovakia and across Europe as a whole, bakery products were in the top three categories of products most likely to be contaminated with foreign bodies.

With regard to fraud specifically, Tähkäpää et al. (2015) compared both RASFF fraud notifications and local Finnish fraud notifications. In order to develop a food fraud risk assessment tool, Marvin et al. (2016) developed a set of variables over and above food fraud type including economic factors (e.g. price, supply and demand); national factors associated 
with the country of origin (e.g. governance) and specific incident related factors such as fraud type, complexity and the potential for fraud detection. The two variables identified by Marvin et al. (2016) with the greatest influence on the type of food fraud committed were country of origin and product. However, care should be taken with simple arithmetic analysis of incidents in RASFF as one incident can skew the frequency of notifications. For example in 2017, fipronil use on egg farms resulted in multiple notifications in RASFF (115 notifications at the time of writing). This creates a challenge when trying to objectively quantify particular types of incidents using RASFF data alone (Bouzembrak \& Marvin, 2016). The potential for a different system of categorisation of incidents between member state databases and RASFF, either by design or by individual inspector discretion, also needs to be considered when drawing comparisons between the two levels of system.

\subsection{Food fraud associated with cereals and bakery products}

The development of fraudulent practices in the food industry is mediated by supply and demand dynamics, trends and current consumption models and any given dietary recommendations. There are multiple examples of authenticity concerns associated with cereals (Pegels, González, García, \& Martín, 2015); and RASFF notifications for bakery (Tähkäpää et al., 2015). Bakery products are characterised by a restricted shelf life, heterogeneity of ingredients, and seasonal variability in product quality due to production and harvesting conditions (Van der Spiegel, Luning, De Boer, Ziggers and Jongen, 2005) whereas dehydrated pasta products have a long shelf life. Adulteration may be motivated not only to mislead or for economic gain, but also to meet stated customer (retailer or food service) requirements. European legislation states that durum wheat pasta can contain a maximum of $3 \%$ of common wheat, so this standard itself may actually incentivise the substitution in the pasta supply chain meeting minimum specifications and deriving best economic return, especially where durum wheat is $25 \%$ more expensive than common wheat (Knödler, Most, Schieber, \& Carle, 2010; 
298 Righetti et al., 2018). Contemporary examples of tainted baked goods include steamed buns in 299 China produced using yellow coloring and sodium cyclamate, an artificial sweetener banned in 300 the United States of America (USA) see China.org.cn (2011) or steamed 'corn buns' sold without corn, but containing flavouring and artificial colours (Everstine, Spink \& Kennedy, 2013) and using dried bakery waste was associated with dioxin contamination in food and feed (Hoogenboom et al., 2004) Thus, there is literature context for malpractice in the cereals supply chain.

\section{Results and discussion}

\subsection{RASFF Database}

The product category cereals and bakery products on the RASFF database was searched for notifications linked to the hazard category adulteration/fraud. There were 42 notifications between 2004 and January 2018, the majority being border rejections $(n=32)$ with information notifications $(\mathrm{n}=8)$ and alerts $(\mathrm{n}=2)$. The non-compliances raised were absence of certified analysis report $(n=27)$, illegal or unauthorised import $(n=6)$, fraudulent health certificate $(n=4)$, improper health certificate $(n=2)$; expiry date change $(n=2)$ and tampering $(n=1)$ with $83 \%$ of the products coming from China or Hong Kong and none linked to Poland. Analysis of incidence by product includes that $83 \%$ of the products were rice, rice products or noodles, with frozen pastry or pies $(n=3)$ and biscuits/cookies $(n=2)$ and cake/cake mix $(n=1)$.

There were 149 notifications for the hazard category composition between 1996 and Jan 2018, with border rejections $(n=76)$, information notifications $(n=35)$ and alerts $(n=38)$. Three further notifications arose as a result of companies' own checks and additional two following customer complaints. The non-compliances raised were high content of aluminium $(n=116)$ mainly associated with noodles and rice products from China, Hong Kong and Vietnam and unauthorised colours including Sudan 1 and Rhodamine B (n=27). Analysis of incidence by product highlights that $74 \%$ were rice, rice products or noodles, pasta $(n=22)$, 
bread/breadcrumbs or flour $(n=7)$, cake/cake mix $(n=3)$, biscuits/cookies $(n=3)$, and frozen pastry or pies $(n=1)$ and three other notifications were for spelt/cereal $(n=1)$ and one for multiple products. There were five incidents associated with Poland.

There were 21 notifications for bakery and cereals products in the hazard category labelling absent/ incomplete/ incorrect between 1996 and Jan 2018, with border rejections $(n=3)$, information notifications $(n=14)$ and alerts $(n=4)$. Insufficient labelling notifications included lack of allergen declaration $(\mathrm{n}=13)$; incorrect labelling e.g. gluten free declarations $(n=6)$ and absence of labelling $(n=2)$. Six notifications were associated with Poland $(29 \%)$ compared with $10 \%$ from China/Hong Kong $(n=2)$. Analysis of incidence by product highlights that whilst $24 \%$ of the products were rice, rice products or noodles, pasta $(n=5)$, biscuits/cookies $(n=8)$ showed the highest incidence of non-compliance, with cake/cake mix $(n=3)$, muesli $(n=2)$, bread/breadcrumbs or flour $(n=1)$, spelt/cereal $(n=1)$ and one more notification for multiple products.

There were 177 notifications for cereal and bakery products associated with Poland between 2004 and January 2018 either because the products may have been notified to RASFF by Poland itself or there was the potential for distribution within Poland. These notifications included both those in the hazard categories already described and other hazard categories within the RASFF database. By notification type, alert was the largest group $(n=92)$, information $(n=62)$ and border rejection $(n=21)$. The notifications were by official controls $(n=105)$, border control rejections $(n=29)$, companies' own checks $(n=24)$, customer complaint $(\mathrm{n}=18)$ and food poisoning $(\mathrm{n}=1)$. The non-compliances raised with the highest frequency were mycotoxins $(n=47)$, undeclared allergens $(n=24)$, undeclared genetically modified material $(n=19)$, pests generally insects and physical contamination from mice $(n=13)$, mould contamination $(n=12)$ and problems with gluten declarations $(n=11)$, organoleptic issues $(n=9)$, metal contamination $(n=7)$, high content of aluminium $(n=5)$, glass contamination $(n=5)$ and 
glycol ( $\mathrm{n}=5$ ), other issues (collectively 30 notifications) had a lower frequency of occurrence. Upon further analysis, there is a potential adulteration incident in 2008 where 3.5 ppm of melamine was found in salty sticks from Poland (RASFF, 2008). This incident coincides with the Chinese melamine contamination of multiple product categories (Gossner et al., 2009). Salty sticks are wheat based Polish snacks and it is speculated that wheat flour used was tainted with melamine. The risk decision was undecided at that time as the adulteration and recall of tainted food from China was beginning to occur. A second incident detected from the analysis was the suspicion of rodenticide granules found in milk powder used to make waffles that were recalled from consumers and were categorised as serious risk although nothing further is reported. Analysis of incidence by product highlights that $26 \%$ of the products were rice, rice products or noodles, pasta $(n=46)$, bread/breadcrumbs or flour $(n=34)$, biscuits/cookies $(n=18)$, cake/cake mix $(n=8)$, linseed (linked to a specific incident $n=8)$ and pasta products $(n=8)$. All other incidents were across a range of products all with lower incidence.

Analysis of the RASFF database allows for identification of bakery products of interest and potential non-compliance that can be compared with the data from Poland. There are notable trends in the data, for example the rise in recent years for notification of incorrect allergen labelling or problems with appropriate labelling of gluten free products perhaps as a result of changes in EU Food Information for Consumers (FIC) Regulations that came into force in 2014, problems with health certification and in two cases a change of expiry date. Other issues that have been identified were undeclared genetically modified material, which is not currently categorised under food fraud/adulteration in the RASFF database.

\subsection{IJHARS Data}

There are 427 administrative decisions publicised on the IJHARS webpage regarding adulterated agri-food items from 2013-2017. It is common that one decision covers several adulterated agri-food items from the same producer, and there are also instances of repeat 
offence by a specific producer. Most non-compliances occur in the following product categories: meat and meat products, flour, cereal and bakery products, delicatessen (ready to serve) products (Figure 1). Other food categories contain 1 to 6 adulteration cases (e.g. food concentrates, non-alcoholic beverages, spices, chocolate products).

\section{Take in Figure 1}

Issues of adulteration of meat/meat products is typical of EU incident datasets that were skewed directly by the 2013 Horsemeat Scandal and analysis of the data presented in the 2016 annual report of the EU Food Fraud Network and the System for Administrative Assistance \& Food Fraud (AAC FF) shows that the most food fraud cases exchanged in the AAC FF concern meat and meat products (26.7\% of all 176 food fraud cases identified). Cereal and bakery products are the second most frequently identified products for food fraud/adulteration in Poland underpinning the rationale to focus on these products. Publicly available IJHARS administrative decisions from the years 2010-2017, comprising 209 adulterated cereal and bakery products marketed by 108 operators were analysed in this study. The large majority of items (94.7\% of all cases) were flour and cereal products (including bread, pasta, baking flour and breadcrumbs), and only 11 agri-food items belonged to the category of pastry, cakes, biscuits and other bakers' wares (including biscuits and waffles). The most commonly reported adulterated cereal and bakery products in Poland were bread and pasta (Figure 2) and in most cases the problem related specifically to mislabelling.

\section{Take in Figure 2}

Mislabelling of this nature could be intentional or unintentional and due simply to human error, lack of verification during product / labelling change in production system or even an error in original artwork design. Other products where non-compliance occurred include corn crunchies, semolina, barley, buckwheat, muesli, matzah, bakery products different than bread 
397

398

399

400

401

402

403

404

405

406

407

408

409

410

411

412

413

414

415

416

417

418

419

('small pizza'), sponge cakes, cupcakes, spit cake, puff pastry, and each one of these was notified only once. IJHARS detected food fraud/ adulteration in the category of cereal and bakery products in each of the 16 provinces in Poland, but most irregularities were identified in West Pomeranian, Kuyavian-Pomeranian and Lubusz Province. The main irregularities in adulterated bread and pasta detected by IJHARS in 2010-2017, from the most to the least frequent, are described in Table 1 and Table 2.

\section{Take in Tables 1 and 2}

The results of IJHARS inspections of cereal and bakery production in 2010-2017 reveal that $98 \%$ of adulterated products were mislabelled. Physicochemical parameters of $18 \%$ of the products were also incompatible with producer's declaration. IJHARS did not identify any problem with organoleptic properties of controlled cereal and bakery products. The most common violations were:

- mislabelling: composition - missing items in the list of ingredients, declaration of ingredients not used in the production process,

- mislabelling: misnomer - incorrect/ incomplete/ no (descriptive) name of the product, and

- mislabelling: method of production - unfounded claim 'no bread improvers', 'no preservatives', 'no chemical additives', 'rustic', 'home', 'traditional recipe', etc.

In Poland, mislabelling is a bigger problem than organoleptic and/or physicochemical noncompliance with a producer's label declaration or specification. The types of mislabelling have been differentiated by product (bread and pasta) and show that composition is the major area of non-compliance with bread whereas method of production was the main area of noncompliance with pasta (Figure 3). 

www.ijhar-s.gov.pl) and with plant-based food products, bread and bakery products were the most frequently mislabelled (Kowalczyk, 2016).

\subsection{Summary}

Analysis of the RASFF and IJHARS databases highlights some challenges when seeking to compare and quantify the incidence of food adulteration. Commercial quality evaluation undertaken by IJHARS is based on three food quality attributes: organoleptic features, physicochemical characteristics and labelling. All mislabelling cases detected by IJHARS are treated as adulteration, but this is not the case with the RASFF system making comparison difficult. The administrative liability of the operator that places adulterated food on the market in Poland is objective (non-judgmental) and the only condition for imposing a sanction is the fact of placing such food on the market. The sanction is determined irrespective of guilt i.e. both intentional and unintentional action are considered as adulteration (Supreme Administrative Court, 2013).

It is important to consider whether the data that has been analysed here reflects the actual level of adulteration in Poland or whether the non-compliance frequency is skewed by riskbased purposive sampling by the IJHARS as is required by legislation such as EU Regulation $2017 / 625$. Therefore it is difficult to determine if mislabelling of cereals and bakery products is becoming a more frequent problem in Poland as the number of inspections that were carried out by IJHARS varied over the time period analysed. There were $7519-9000$ IJHARS inspections carried out on the domestic market in 2010 - 2013, 11675 inspections in 2014, 12 220 inspections in 2015, and 35169 inspections in 2016 i.e. there were four times as many inspections in 2016 than in 2010. On the other hand, the number of IJHARS inspections at 
444 import and export stage decreased from 80 - 90000 in 2010-2014 to 60000 in 2015-2016.

445 There have been additional 3 - 4000 IJHARS inspections carried out annually on request of 446 institutions cooperating with IJHARS (see http://www.ijhar-s.gov.pl) and the areas that 447 IJHARS covers by their planned inspections depended as previously described on purposive 448 risk-based analysis and the input of businesses they inspect. database and the data regarding the decisions made by IJHARS arises from the essence of the systems themselves. IJHARS carries out planned and ad hoc inspections on both the domestic Polish market and at import and export stages. These inspections are particularly concerned with the marketing quality of commonly consumed products dairy products, meat, fish, cereals, processed fruit and vegetables, ready-to-cook food, honey, eggs, and fresh fruit and vegetables (see http://www.ijhar-s.gov.pl). There is some equivalent in EU member state in terms of domestic databases such as the UK Food Surveillance System (UKFSS), see FSA (2018) or the Finnish Food Safety Authority EVIRA system (Tähkäpää et al., 2015). However the data within the RASFF database is in part driven by different regulatory criteria i.e. purposive risk-based import sampling of specific countries and products. Further the dataset within the RASFF system for adulteration is relatively small so a few incidents can quickly change the overall metrics that are derived and the categories used within RASFF are very broad and worthy of redefinition to aid better isolation of incidents and trend analysis. Where categories are not aligned within national databases and the RASFF this means it is difficult to analyse the combined data for trends and emerging risk without undertaking an in-depth assessment of the multiple datasets.

What are the key factors that can be drawn out here from the analysis of the IJHARS 467 system? Bread, an integral part of the Polish diet, represents over $67 \%$ of the reported cereal 468 and bakery incidents on the IJHARS database. The main irregularities highlighted were missing 
items in the ingredients list, a lack of, or incorrect description of, the type of flour used; misleading or no information at all on the percentage of some ingredients e.g. sunflower seeds, and unfounded claims on the method of production. These findings undermine confidence in the integrity of bakery products in Poland.

Further it is important to consider the definition of adulteration is actually of value here. Article 3 of the Polish Act on Safety of Food and Nutrition, states an adulterated foodstuff is one whose composition or other properties are changed without informing the consumer about it, or a foodstuff changed in order to conceal its intrinsic composition or other properties, and affecting the safety of the foodstuff. Global Food Safety Initiative (GFSI) Position Statement on mitigating the public health risk of food fraud (July 2014) identifies both intentional adulteration and unintentional/accidental adulteration whereas other sources state that for adulteration to be considered as a subset of food fraud it can only be determined as being intentional (Elliott Review, 2014). This lack of harmonisation of definitions proves challenging. The health implications of food adulteration are complex too. If it is an allergen that is used as an adulterant and then undeclared on labelling this obviously will have health implications e.g. the use of peanut powder in almond powder as an a cheaper "filler". The multiple materials that could be used to adulterate combined with the often lack of immediate, valid data on their health impact when discovered e.g. melamine in wheat gluten means that any investigations are reactive in nature and thus response at regulatory and market level can appear slow to consumers. The economic consequences are implicit in food adulteration. In a given food supply chain there are normative, coercive and mimetic (economic) pressures from respectively lobby groups, consumer, criminal groups, coercive and political pressures from government, buyers and sellers etc. (Kilbourne, Beckmann \& Thelen, 2002), and mimetic pressures which emerge from horizontal competition (Zhu, Sarkis \& Geng, 2005; Aerts, Cormier, \& Magnan, 2006; Sarkis, Gonzalez-Torre \& Adenso-Diaz, 2010) that operate at individual levels primary, 
secondary, tertiary production and also at the interfaces between levels. Mimetic pressure can be specifically exerted where there is an asymmetry in supply chain power between two or more actors/stakeholders creating vulnerabilities where the potential for adulteration can occur giving rise to illicit behaviour. There is limited independent data on the economic impact of food adulteration and much of that is contained within wider estimates of food fraud e.g. European Epson activities or estimations are based on extrapolation of data from studies to the wider supply chain which are limited as a result because of the embedded generalisations used. Ultimately, placing adulterated food on the market is an action of unfair practice that promotes the competitiveness of the perpetrator whilst undermining the competitiveness of other operators within the sector.

\section{Conclusion}

Cereal products especially bread and baked goods are an important part of the Polish economy especially for local producers and manufacturers underpinned by effective food safety and product standards management systems and controls. As Poland is one of the top producers and exporters of cereal products in the EU, there is further potential for marketing and exporting a variety of Polish origin bakery products. IJHARS carries out comprehensive inspections of goods locally and at import/export interfaces. As the food chain becomes more global, it is crucial that IJHARS remains vigilant in ensuring the safety and legality of food products especially as has been highlighted in this paper with regard to product labelling. The official controls in Poland are also supported by the EU RASFF system that focuses on the entry and exit of safe and legal food into and across the European market.

This paper has focused on definitions and interpretation of the term adulteration especially in the Polish context. Food can be placed on the market whereby its associated labelling is misleading either inadvertently or intentionally and this has been a challenge highlighted in this paper. Unintentional adulteration can occur as the result of a lack of 
519 knowledge, facilities or resources. The definition of adulterated foodstuffs in Poland

520

521

522

523

524

525

526

527

528

529

530

531

532

533

534

535

536

537

538

539

540

541

542

543

544

545

546

concentrates on mislabelling particularly regarding product composition rather than being differentiated by the motivation of the perpetrator e.g. that an individual undertakes adulteration for financial gain (EMA) or to overcome a challenge between the demand for a finished product and the ability to access sufficient ingredients of the correct provenance. This study demonstrates that even in harmonized regulatory areas such as the EU there are local legal definitions of adulteration and these may, or may not, concur with definitions of adulteration in private market standards. A lack of consistency and commonality in definitions could influence collective approaches to determining the extent of or addressing the problem of mislabelling, misrepresentation and misbranding as forms of adulteration at national level and across national border trading such as in the EU. This research shows that more empirical work needs to be undertaken to contextualise the drivers for misbranding, mislabelling and misrepresentation in the food supply chain and for this problem to be seen not just as a subset of food fraud (see Spink and Moyer, 2011), but as a problem worthy of study in its own right. Empirical work needs to place particular attention on how data has been collected within existing regulatory and private databases and the constraints this then places on generalising the results of study work on a range of products and contexts. Research on labelling integrity should be multidisciplinary and focus on food labelling from both a legal and ethical perspective.

\section{References}

Aerts, W., Cormier, D., and Magnan, M. (2008). Corporate environmental disclosure, financial markets and the media: An international perspective. Ecological Economics, 64(3), 643-659.

Amiry, S., Esmaiili, M. \& Alizadeh, M. (2017). Classification of adulterated honeys by multivariate analysis, Food Chemistry, 224, 390-397.

Bandal, S., Singh, A., Mangal, M., Mangal, A.K., \& Kumar, S. 2017. Food adulteration: Sources, health risks, and detection methods, Critical Reviews in Food Science and Nutrition 57(6): 1174-1189. http://dx.doi.org/10.1080/10408398.2014.967834. 
547 Bouzembrak, Y., \& Marvin, H. J. P. (2015). Prediction of food fraud type using data from 548 Rapid Alert System for Food and Feed (RASFF) and Bayesian network modelling. Food 549 Control, 61, 180-187.

550 BRC. (2015). British Retail Consortium Global Standard Food Safety. Issue 7. BRC, London.

551 Charlebois, S., Schwab, A., Henn, R., \& Huck, C. W. (2016). Food fraud: An exploratory study for measuring consumer perception towards mislabelled food products and influence on self-authentication intentions. Trends in Food Science \& Technology, 50, 211-218.

554 China.org.cn (2011). Shanghai apologizes for tainted steamed buns. Available at:

555 http://www.china.org.cn/china/2011-04/15/content 22365722.htm (Accessed on 22nd

556 January 2018)

557 Cozzolino, D. (2016). Authentication of Cereals and Cereal Products. In Advances in Food 558 Authenticity Testing, 441-457.

559 CSO (Central Statistical Office). (2017). Statistical Yearbook of Agriculture 2016. Statistical 560 Information and Elaborations. Warsaw.

561 CSO (Central Statistical Office). (2016a). Foreign trade. January - December 2015. Statistical 562 Information and Elaborations. Warsaw.

563 CSO (Central Statistical Office). (2016b). Household budget survey 2015. Statistical 564 Information and Elaborations. Warsaw.

565 CSO (Central Statistical Office). (2016c). Statistical Yearbook of Agriculture 2015. Statistical 566 Information and Elaborations. Warsaw.

567 Czyżewski, A., Staniszewski, J. (2016). Land and labour productivity in Polish agriculture 568 against highly-developed countries of the European Union. Acta Scientiarum Polonorum. 569 Seria: Oeconomia, 15(4), 53-63.

570 Djekic, I., Jankovic, D. \& Rajkovic, A. (2017). Analysis of foreign bodies present in 571 European food using data from Rapid Alert System for Food and Feed (RASFF). Food 572 Control, 79, 143-149.

573 Elliott Review. (2014). Elliott Review into the integrity and assurance of food supply 574 networks - final report a national food crime prevention framework. HM Government July 575 2014. London.

576 EU 2017/625 (2017). Regulation (EU) 2017/625 of the European Parliament and the Council 577 of 15 March 2017 on official controls and other official activities performed to ensure the 578 application of food and feed law, rules on animal health and welfare, plant health and plant 579 protection products. Available at: http://eur-lex.europa.eu/legal-

580 content/EN/TXT/?uri=CELEX\%3A32017R0625 (Accessed on $5^{\text {th }}$ December 2017)

581 EU. (2016). The EU Food Fraud Network and the System for Administrative Assistance \& 582 Food Fraud. Annual report 2016 [Online]. Available at:

583 https://ec.europa.eu/food/sites/food/files/safety/docs/food-

584 fraud_network_activity_report_2016.pdf. (Accessed on 8th June 2017).

585 EU 1151/2012 (2012). Regulation (EU) No 1151/2012 of the European Parliament and of the 586 Council of 21 November 2012 on quality schemes for agricultural products and foodstuffs. 
Available at: http://eur-lex.europa.eu/legal-content/EN/TXT/?uri=CELEX\%3A32012R1151 (Accessed on 10 ${ }^{\text {th }}$ December 2017)

Europa (nd), Agricultural Production - Crops Available at http://ec.europa.eu/eurostat/statistics-explained/index.php/Agricultural_production___crops, (Accessed $5^{\text {th }}$ December 2017)

Everstine, K., Spink, J. \& Kennedy, S. (2013). Economically motivated adulteration (EMA) of food: Common characteristics of EMA incidents. Journal of Food Protection, 76(4), 723735 .

FSA (Food Standards Agency). (2018). UK Food Surveillance System. Available at: https://www.food.gov.uk/enforcement/sampling/fss (Accessed on 2nd January 2018)

Galvin-King, P., Haughey, S.A. \& Elliott, C.T., (2017). Herb and spice fraud; the drivers, challenges and detection. Food Control, 88, 85-97.

Garrido-Delgado, R., Munoz-Perez, M. E. \& Arce, L. (2018). Detection of adulteration in extra virgin olive oils by using UV-IMS and chemometric analysis, Food Control, 85, 292299.

Geng, P., Harnly, J.M. \& Chen, P. (2016). Differentiation of bread made with whole grain and refined wheat (T. aestivum) flour using LC/MS-based chromatographic fingerprinting and chemometric approaches. Journal of Food Composition and Analysis, 47, 92-100.

GFSI. (2014). (Global Food Safety Initiative). GFSI Position on mitigating the public health risk of food fraud July 2014. Available from: http://www.mygfsi.com/newsresources/news/295-gfsi-position-paper-on- mitigating-the-public-health-risk-of-foodfraud.html. (Accessed on 4th December 2017).

Głowacka, A., Zych, M., \& Żołnierczuk, J. (2016). Environmental and economic effects of the use of grain oat for energy purposes. Ecological Engineering, 49, 117-123.

Gossner, C. M.E., Schlundt, J., Embarek, P. B., Hird, S., Lo-Fo-Wong, D., Beltran, J. J. O. et al. (2009). The melamine incident: Implications for international food and feed safety. Environmental Health Perspective, 117(12), 1803-1808.

Hoogenboom, R., Bovee, T., Portier, L., Bor, G., van der Weg, G., Onstenk, C. \& Traag, W., (2004). The German bakery waste incident; use of a combined approach of screening and confirmation for dioxins in feed and food. Talanta, 63(5), 1249-1253.

Kawka, A., \& Achremowicz, B. (2014). Oat - XXI century plant. Nutrition and industrial use. Science Nature Technologies, 9(3), 1-12.

Kilbourne, W.E., Beckmann, S.C. and Thelen, E., (2002). The role of the dominant social paradigm in environmental attitudes: A multinational examination. Journal of Business Research, 55(3), 193-204.

Kleter, G. A., Prandini, A., Filippi, L. \& Marvin, H.J.P. (2009). Identification of potentially emerging food safety issues by analysis of reports published by the European community's 
625 Rapid Alert System for Food and Feed (RASFF) during a four-year period. Food Chem.

626 Toxicol, 47(5), 932-950.

627 Knapowski, T., Kozera, W., Wszelaczyńska, E., Pobereżny, J., Cieślewicz, J., \&

628 Chmielewski, J. (2017). The effect of environmental conditions on the content of selected 629 micronutrients in spelt grain. Environmental Protection and Natural Resources, 28(3), 26-31.

630 Knödler, M., Most, M., Schieber, A. \& Carle, R. (2010). A novel approach to authenticity 631 control of whole grain durum wheat (Triticum durum Desf.) flour and pasta, based on 632 analysis of alkylresorcinol composition. Food Chemistry, 118(1), 177-181.

633 Kölbener, P., Bieri, S., \& St-Gallen, C. (2016). Food Fraud and Adulteration, a Centuries-old 634 Practice. CHIMIA International Journal for Chemistry, 70(5), 317-317.

635 Kowalczyk, S. (2015). Authenticity of food products in the Polish market checked during 636 2005-2012. Annals of the National Institute of Hygiene, 66(1), 27-34.

637 Kowalczyk, S. (2016). Food safety and quality. PWN SA. Warsaw.

638 Kowalska, A. (2017). An issue of food losses and waste and its determinants. LogForum, 639 13(1), 7-18.

640 Kowalska, A. (2010). Quality and competitiveness issues in organic agriculture. Difin SA. 641 Warsaw.

642 Manning, L., Smith, R., \& Soon, J.M. (2016). Developing an Organizational Typology of 643 Criminals in the Meat Supply Chain, Food Policy, 59, 44-54

644 Manning L. (2016). Food Fraud, policy and food chain, Current Opinions in Food Science, $645 \quad 10,16-21$

646 Manning, L \& Soon, J.M, (2014). Developing systems to control food adulteration, Food 647 Policy, 49(1), 23-32

648 Marvin, H. J., Bouzembrak, Y., Janssen, E. M., van der Fels-Klerx, H. J., van Asselt, E. D., \& 649 Kleter, G. A. (2016). A holistic approach to food safety risks: Food fraud as an example.

650 Food Research International, 89, 463-470.

651 Moore, J.C., Spink, J. \& Lipp, M., (2012). Development and application of a database of food 652 ingredient fraud and economically motivated adulteration from 1980 to 2010. Journal of Food 653 Science, 77(4), R118-R126.

654 Murniece, I. \& Straumite, E. (2014). The information presented on labels for bread produced 655 in Latvia. Food Chemistry, 162, 117-121.

656 Pegels, N., González, I., García, T. \& Martín, R. (2015). Authenticity testing of wheat, barley, 657 rye and oats in food and feed market samples by real-time PCR assays. LWT-Food Science 658 and Technology, 60(2), 867-875

659 Pinto-Sánchez, M.I., Causada-Calo, N., Bercik, P., Ford, A.C., Murray, J.A., Armstrong, D., 660 Semrad, C., Kupfer, S.S., Alaedini, A., Moayyedi, P., Leffler, D.A., Verdú, E.F., \& Green, P. 661 (2017). Safety of Adding Oats to a Gluten-Free Diet for Patients With Celiac Disease: 
662 Systematic Review and Meta-analysis of Clinical and Observational Studies.

663 Gastroenterology, 153(2), 395-409.

664 Pohjanheimo, T., Paasovaara, R., Luomala, H., \& Sandell, M. (2010). Food choice motives 665 and bread liking of consumers embracing hedonistic and traditional values. Appetite, 54, 170666180.

667 RASFF (Rapid Alert System for Food and Feed) (2017). RASFF Portal, Available at 668 https://ec.europa.eu/food/safety/rasff/portal_en (Accessed on 4th December 2017)

669 RASFF (Rapid Alert System for Food and Feed) (2008). Notification details - 2008.1671.

670 Available at: https://webgate.ec.europa.eu/rasff-

671 window/portal/?event=notificationDetail\&NOTIF_REFERENCE=2008.1671 (Accessed on $672 \quad 22^{\text {nd }}$ January 2018)

673 Righetti, L., Rubert, J., Galaverna, G., Hurkova, K., Dall'Asta, C., Hajslova, J. \& Stranska674 Zachariasova, M. (2018). A novel approach based on untargeted lipidomics reveals 675 differences in the lipid pattern among durum and common wheat. Food Chemistry, 240, 775676783.

677 Sarkis, J., Gonzalez-Torre, P., \& Adenso-Diaz, B. (2010). Stakeholder pressure and the 678 adoption of environmental practices: The mediating effect of training. Journal of Operations 679 Management, 28(2), 163-176.

680 Scally, G. (2013). Adulteration of food: what it doesn't say on the tin, British Medical 681 Journal, 346, 1463.

682 Silvis, I. C. J., van Ruth, S. M., van der Fels-Klerx, H. J., \& Luning, P. A. (2017). Assessment 683 of food fraud vulnerability in the spices chain: An explorative study, Food Control, 81, 80-87

684 Śmiechowska, M., \& Chrzanowska, B. (2015). An attempt to determine the causes of food 685 waste in households on the example of bread. Annals of The Polish Association of 686 Agricultural and Agribusiness Economists, 17(2), 237-241.

687 Spink, J. \& Moyer, D.C. (2011). Backgrounder: Defining the Public Health Threat of Food 688 Fraud, in Research Grants, National Center for Food Protection and Defense (NCFPD), 689 Minneapolis, MN, p. 7, Available from: www.ncfpd.umn.edu (Accessed 4 December 2017).

690 Stanisławska, J., \& Kurzawa, I. (2016). Consumption of Bread and Cereal Products in 691 Households in Poland, According to Socio-Economic Groups. Studia i Prace WNEiZ US, $6923(43), 391-401$.

693 Supreme Administrative Court (2013). The Judgment of 6 February 2013 in Case the liability 694 for placing adulterated butter on the market. II GSK 2171/11.

695 Świetlik, K. (2017). Quantitative and qualitative changes in the consumption of food in 696 Poland, Food Industry, 71(7), 2-7.

697 Tähkäpää, S., Maijala, R., Korkeala, H., \& Nevas, M. (2015). Patterns of food frauds and 698 adulterations reported in the EU rapid alert system for food and feed and in Finland. Food 699 Control, 47, 175-184. 
700 The Act on Commercial Quality of Agricultural and Food Products as of December 21, 2000

701 (Journal of Laws of the Republic of Poland, 2000, No 5, item 44, as amended).

702 The Act on the Prevention of Unfair Use of Contract Advantage in Manufacturing of

703 Agricultural and Food Products as of December 15, 2016 (Journal of Laws of the Republic of

704 Poland, 2017, item 67).

705 The Act on the Safety of Food and Nutrition as of August 25, 2006 (Journal of Laws of the

706 Republic of Poland, 2006, No 171, item 1225, as amended).

707 Trafiałek, J., \& Kołożyn-Krajewska, D. (2011). Implementation of Safety Assurance System

708 in Food Production in Poland. Polish Journal of Food And Nutrition Sciences, 61(2), 115-

709124.

710 Van Der Spiegel, M., Luning, P.A., De Boer, W.J., Ziggers, G.W. \& Jongen, W.M.F., (2005).

711 How to improve food quality management in the bakery sector. NJAS-Wageningen Journal of

712 Life Sciences, 53(2), 131-150.

713 Zhu, Q., Sarkis, J., \& Geng, Y. (2005). Green supply chain management in China: pressures,

714 practices and performance. International Journal of Operations and Production Management, 715 25(5), 449-468.

716 


\begin{tabular}{|l|r|r|}
\hline \multicolumn{1}{|c|}{ Bread (139 cases) } & $\begin{array}{r}\text { Type of irregularity } \\
\text { No of } \\
\text { cases }\end{array}$ & $\begin{array}{r}\text { Share of } \\
\text { the bread } \\
\text { cases }\end{array}$ \\
\hline $\begin{array}{l}\text { Missing items in the list of ingredients, i.e. bread improver, constituents of a } \\
\text { compound ingredient (usually bread improver), ascorbic acid, food additives } \\
\text { approved for use, anti-mould substance). }\end{array}$ & 67 & $48.2 \%$ \\
\hline $\begin{array}{l}\text { A lack off, or incorrect description of bread type e.g. type of flour used, e.g. mixed, } \\
\text { wheat or rye }\end{array}$ & 44 & $31.7 \%$ \\
\hline $\begin{array}{l}\text { Storage conditions and durability - no information about 'use-by date'/storage } \\
\text { conditions }\end{array}$ & 16 & $11.5 \%$ \\
\hline $\begin{array}{l}\text { Method of production - unfounded claim 'no bread improvers', 'no preservatives', } \\
\text { 'no chemical additives', 'rustic', 'home', 'traditional recipe', etc. }\end{array}$ & 14 & $10.1 \%$ \\
\hline Declaration of ingredients not used in the production process & 13 & $9.4 \%$ \\
\hline No reference to allergens e.g. wheat gluten, barley malt, soy flour, sesame seeds & 12 & $8.6 \%$ \\
\hline $\begin{array}{l}\text { No/misleading information about content percentage of an ingredient, e.g. wholemeal } \\
\text { flower, sunflower seeds, soybeans }\end{array}$ & 11 & $7.9 \%$ \\
\hline Understatement of net weight & 9 & $6.5 \%$ \\
\hline
\end{tabular}

Source: Own elaboration based on http://www.ijhar-s.gov.pl.

Table 2. Main irregularities detected by IJHARS in adulterated pasta (2010-2017)

\begin{tabular}{|l|c|c|}
\hline \multicolumn{1}{|c|}{ Pasta (34 cases) } & No of & $\begin{array}{c}\text { Share of } \\
\text { the pasta } \\
\text { cases }\end{array}$ \\
\hline Cype of irregularity & $\begin{array}{c}\text { Nases } \\
\text { Underestimation of eggs content }\end{array}$ & $50.0 \%$ \\
\hline Underestimation of fat content & 7 & $23.5 \%$ \\
\hline Lack of term "with turmeric spices" in the name of a product & 6 & $20.6 \%$ \\
\hline Missing items in ingredients list & 5 & $17.6 \%$ \\
\hline Method of production, e.g. unfounded claim "home" & 4 & $14.7 \%$ \\
\hline Declaration of ingredients not used in the production process & $71.8 \%$ \\
\hline
\end{tabular}

Source: Own elaboration based on http://www.ijhar-s.gov.pl. 
Figure 1. IJHARS administrative decisions concerning adulteration per product category (2013-1017)

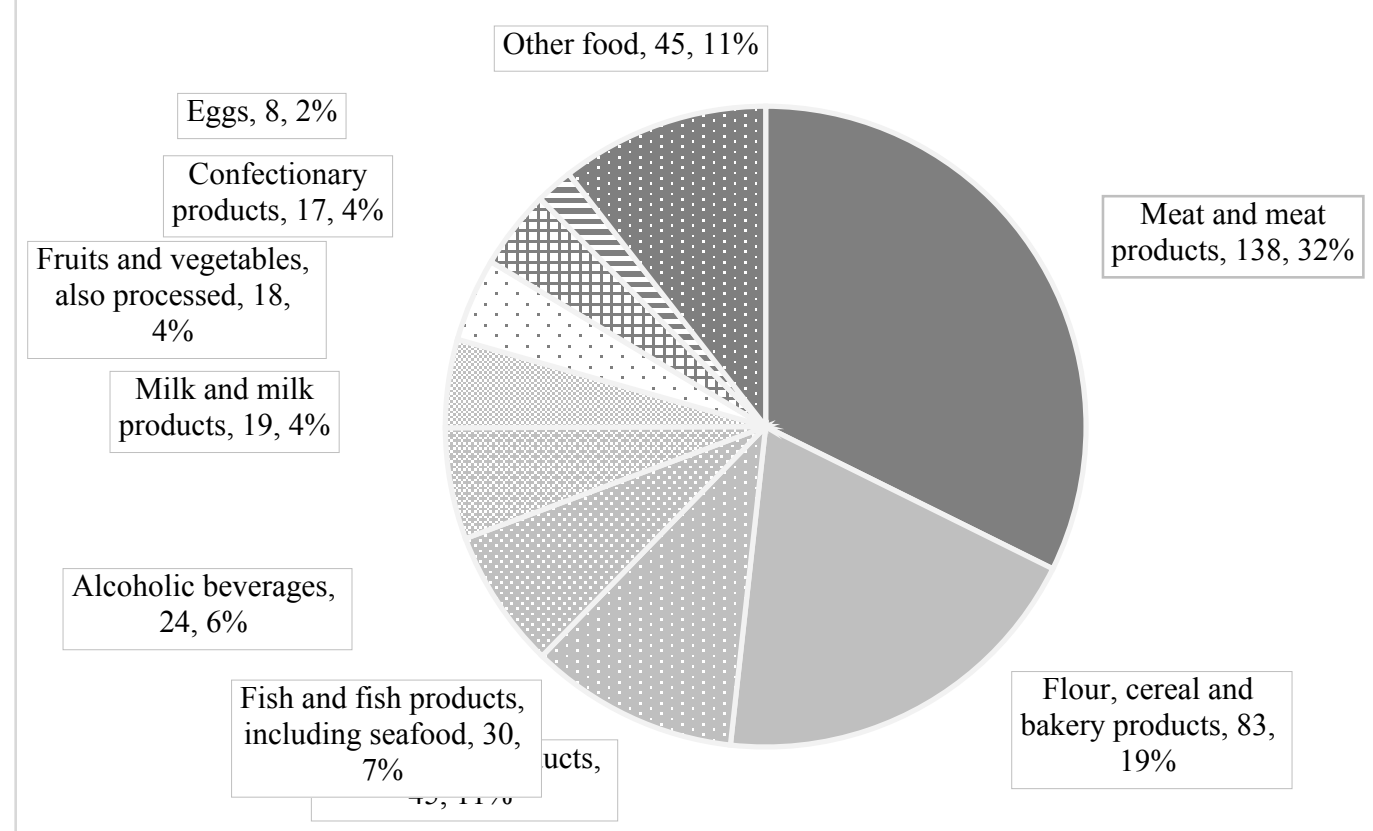

\section{Source: Own elaboration based on http://www.ijhar-s.gov.pl}

Figure 2. Reported types of cereal and bakery products in Poland in 2010-2017 within

\section{Breadcrumbs, $3,1 \%$}

Flour, $3,1 \%$ y wafers, $8,4 \%$

Biscuits, 7, 3\%

$$
5 \%
$$

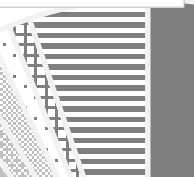

Pasta, 34, 16\%

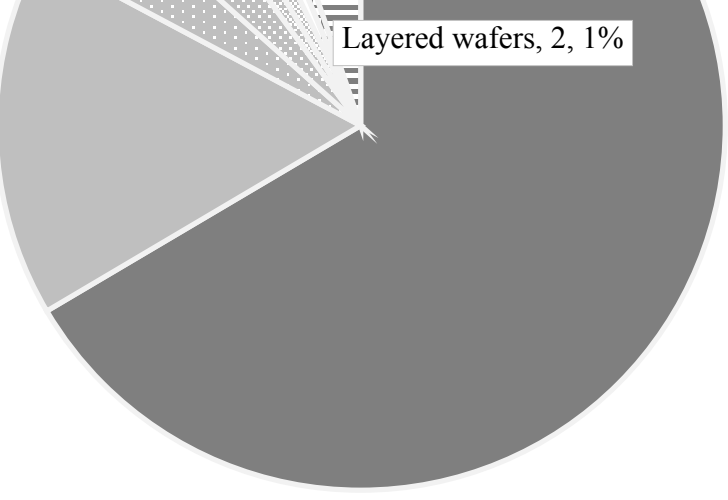

Source: Own elaboration based on http://www.ijhar-s.gov.pl. 
Figure 3. The percentage of the main mislabelling irregularities in adulterated bread 734 and pasta $(2010-2017)$

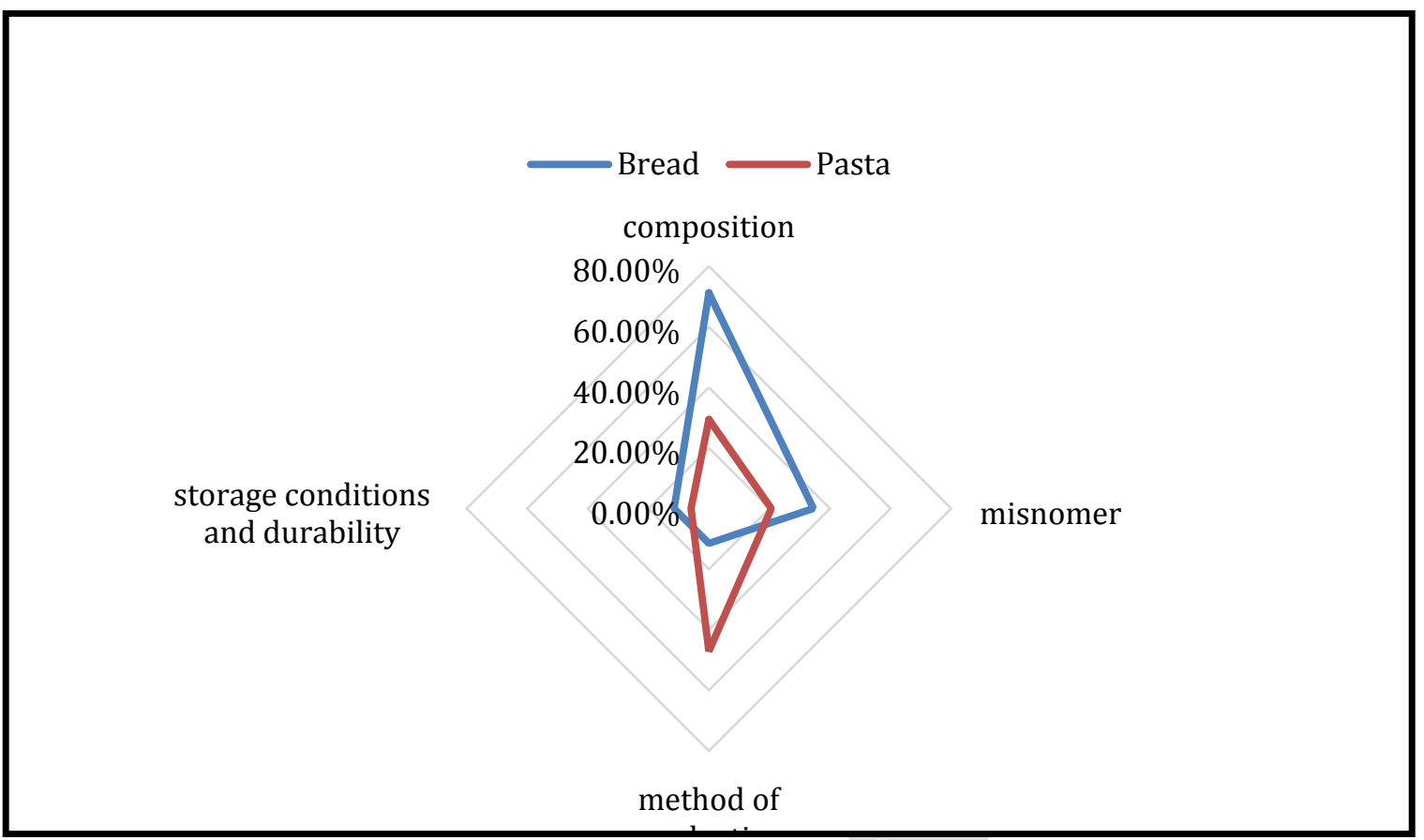

Source: Own elaboration based on http://www.ijhar-s.gov.pl. 